\title{
OPTIMALISASI PROSES GERINDA UNTUK PERMUKAAN
}

\author{
ARYA MAHENDRA SAKTI \\ Jurusan Teknik Mesin FT-Unesa Kampus Unesa Ketintang Surabaya \\ E-mail: aryasakti_2006@yahoo.com
}

\begin{abstract}
ABSTRAK
Pada dasarnya, gerinda permukaan adalah proses mekanik yang menghasilkan temperatur tinggi dan reaksi kimia pada permukaan benda kerja. Pada proses ini, energi panas dikeluarkan di sepanjang permukaan benda kerja. Sebagian energi akan diubah bentuk menjadi serpihan material dan sebagian yang lain akan tetap berada lingkungan kerja, di antara gerinda dan benda kerja. Penggunaan pendingin di permukaan benda kerja berfungsi sebagai pelumas, yang mana dapat mengurangi gesekan antara gerinda dan benda kerja. Lebih jauh lagi, pada proses gerinda, pendinginan dapat berdampak pada temperatur dan kekasaran permukaan. Penelitian ini menggunakan desain eksperimen faktor $2 \times 3 x 3$ untuk mengevaluasi efek beberapa variabel proses, seperti kecepatan, kedalaman pemotongan, dan juga metode pendinginan pada temperatur dan kekasaran permukaan. Udara bertekanan tinggi dan udara pada temperatur ruangan adalah jenis metode yang digunakan pada proses ini. Hasil penelitian ini akan dianalisis dengan ANOVA. Hasil penelitian menunjukkan bahwa temperatur yang dihasilkan pada udara bertekanan tinggi lebih rendah daripada udara pada temperatur ruangan. Benda kerja yang digerinda dengan metode pendinginan udara menghasilkan kekasaran permukaan terendah. Semakin cepat kecepatan meja mesin gerinda, semakin rendah temperatur gerinda yang dihasilkan dan semakin rendah pula kekasaran permukaannya. Lebih jauh lagi, semakin besar kedalaman pemotongan, semakin besar pula temperatur yang dihasilkan dan semakin besar pula kekasaran permukaannya.
\end{abstract}

Kata kunci: gerinda permukaan, temperatur gerinda, kekasaran permukaan

\begin{abstract}
Basically, surface grinding is mechanical process that result high temperature and chemical reaction on surface work piece. On this process, the heat energy has been released along of the surface. A part of the energy would be transferred to chip and the other would be continued to the environment by grinder and work piece. Use of coolant on the surface of the object will be function as lubricant, which can reduce friction between grinder and the object. Moreover, in grinding process, cooling can effect on temperature and surface roughness. This research used factorial design $2 x 3 x 3$ to evaluate the effect some variables process such as table speed, depth of cut also cooling method on temperature and surface roughness. High pressure air and air in room temperature are kinds of cooling method in the process, the result of experiment would be analysis by ANOVA. The experiment shows that temperature in air cooling method it is lower than by air of room temperature cooling method. The surface roughness of the work piece in air cooling method is the lowest. The faster table speed of grinding machine caused that the lower of the grinding temperature and the work piece surface roughness. Moreover, the higher depth of cut would cause the higher grinding temperature and surface roughness.
\end{abstract}

Keywords: surface grinding, grinding temperature, surface roughness

\section{PENDAHULUAN}

Gerinda pada dasarnya adalah proses mekanik yang menimbulkan temperatur tinggi dan reaksi kimia pada permukaan benda kerja. Proses gerinda permukaan terdapat energi yang dikeluarkan dalam bentuk perpindahan panas di sepanjang permukaan benda kerja. Guo (1996) menjelaskan proses penghalusan permukaan memerlukan suatu masukan energi yang sangat besar dari tenaga per volume satuan dari bahan yang dipakai. Panas yang dihasilkan pada proses gerinda permukaan akan berpengaruh terhadap hasil kekasaran permukaan benda kerja. Untuk proses gerinda permukaan hampir sebagian besar panas (80\% sampai dengan 85\%) mengalir melalui benda kerja. Babic (2000) menjelaskan kekasaran permukaan proses gerinda dilihat dari temperatur tinggi di sepanjang permukaan benda kerja. Melihat temperatur lokal yang tertinggi dapat diketahui titik mana saja yang menyebabkan terjadinya pendistribusian panas tertinggi pada permukaan benda kerja yang mengalami pengerjaan gerinda permukaan.

Pemakaian cairan pendingin akan berpengaruh terhadap hasil kekasaran permukaan benda kerja. 
Cairan pendingin yang diberikan pada permukaan benda kerja akan berfungsi sebagai pelumas, sehingga dapat mengurangi gesekan antara pahat gerinda dengan benda kerja. Jannone (2002) menjelaskan bahwa cairan pendingin yang digunakan pada proses penggerindaan akan memengaruhi hasil permukaan pemotongan benda kerja, dan menggunakan empat macam cairan pendingin yang berbeda, yaitu synthetic, semi synthetic, soluble oil, cutting oil, serta menggunakan dua macam batu gerinda yaitu alumina dan CBN (Cubic Boron Nitride). Kedalaman pemakanan juga berpengaruh terhadap kakasaran permukaan. Semakin besar kedalaman pemakanan yang digunakan, maka tingkat kekasaran permukaan benda kerja akan semakin besar atau kasar. Nguyen (2003) menjelaskan bahwa selain perbedaan cairan pendingin yang sangat berpengaruh terhadap permukaan hasil penggerindaan, kedalaman pemotongan juga berperan terhadap penyebaran panas yang ditimbulkan pada permukaan hasil pemotongan.

Dhar (2006) menjelaskan bahan cairan pendingin yang disemprotkan dengan tekanan tinggi akan membantu proses penggerindaan secara menyeluruh. Penggunaan cairan pendingin bertekanan tinggi akan mengurangi penyebaran distribusi panas dan mengurangi pengikisan batu gerinda. Pendinginan dengan tekanan tinggi juga akan membuat cairan pendingin berfungsi sebagai pelumas pada permukaan benda kerja.

Melihat hasil-hasil penelitian terdahulu, maka perlu dilakukan suatu penelitian lanjutan untuk mengetahui pengaruh dari metode pendinginan, kedalaman pemakanan, dan kecepatan meja terhadap temperatur daerah penggerindaan dan kekasaran permukaan yang terjadi pada proses gerinda permukaan baja AISI 1045. Tujuan penelitian ini dapat mengetahui keterkaitan antara perbedaan kedalaman pemakanan, kecepatan meja, dan pendinginan dengan temperatur penggerindaan dan kekasaran permukaan pada proses gerinda permukaan. Sehingga bisa mendapatkan cara terbaik untuk memperoleh setting alat yang bisa menghsilkan temperatur permukaan dan kekasaran permukaan benda kerja yang terendah.

\section{METODE}

Tujuan dari penelitian ini adalah untuk mengetahui pengaruh dari penggunaan udara bertekanan tinggi (UBT), kecepatan meja benda kerja dan kedalaman pemakanan terhadap temperatur dan kekasaran permukaan hasil penggerindaan dengan gerinda permukaan (surface grinding). Sebagai pembanding, juga dilakukan eksperimen penggerindaan tanpa menggunakan cairan pendingin atau dalam kondisi kering. Oleh karena itu, rancangan eksperimen yang digunakan adalah rancangan faktorial $2 \times 3 \times 3$ model efek tetap. Variabel respon pada penelitian ini adalah temperatur dan kekasaran permukaan benda kerja hasil penggerindaan. Sebagai variabel bebas adalah kondisi penggerindaan, kecepatan meja dan kedalaman pemakanan. Kondisi penggerindaan memiliki dua level, yaitu UBT dan kering. Ada tiga level kecepatan meja benda kerja, yaitu $132 \mathrm{~mm} / \mathrm{s}$, $191 \mathrm{~mm} / \mathrm{s}$ dan $250 \mathrm{~mm} / \mathrm{s}$. Kedalaman pemakanan juga memiliki tiga level, yaitu $0.01 \mathrm{~mm}, 0.02 \mathrm{~mm}$ dan $0.03 \mathrm{~mm}$. Eksperimen dilakukan secara acak tanpa replikasi. Dengan demikian diperoleh 18 observasi untuk eksperimen. Prosedur penelitian yang akan dilakukan adalah menyiapkan benda kerja dengan ukuran $50 \mathrm{~mm} \times 20 \mathrm{~mm} \times 20 \mathrm{~mm}$, dan juga siapkan peralatan surface grinding, kompresor udara, dan data akusisi temperatur. Pasang termokopel ke dalam benda kerja dan sambungkan dengan data akusisi temperatur, serta pasang benda kerja ke ragum yang menempel ke permukaan meja benda kerja yang mengandung magnet. Lakukan setting peralatan sesuai variabel yang diinginkan dan juga kalibrasi pada perangkat data akusisi temperatur. Pengambilan data temperatur dimulai dari spesimen kering, dan dilanjutkan dengan udara bertekanan tinggi. Bersihkan permukaan benda kerja sampai bersih dan kering, kemudian dilanjutkan dengan pengambilan data kekasaran permukaan benda kerja. Data temperatur dan kekasaran permukaan yang telah kita peroleh dilakukan analisis menggunakan software minitab 14.

\section{HASIL DAN PEMBAHASAN}

Setelah dilakukan penelitian dengan prosedur yang diuraikan apada metode, didapatkan hasil bahwa faktor kondisi penggerindaan dan kecepatan meja tidak berpengaruh, akan tetapi pada kedalaman pemakanan berpengaruh, secara statistik mempunyai pengaruh yang signifikan pada alpha $=10 \%$. Hal ini diketahui dengan menggunakan analisis variansi yang hasilnya ditunjukkan pada Tabel 1 .

Kemudian, dilakukan Uji Duncan untuk mengetahui pengaruh kecepatan meja dan kedalaman pemakanan. Hasil dari Uji Duncan disajikan pada Tabel 2 dan Tabel 3. Hasil uji Duncan yang ditunjukkan pada Tabel 2 bahwa ketiga level kecepatan meja adalah sama. Sedangkan pada tabel 3 menunjukkan level 0,01 dan 0,02 pada kedalaman pemakanan adalah sama, tetapi berbeda dengan kedalaman pemakanan pada level 0,03.

Gambar 1 menunjukkan temperatur hasil penggerindaan dengan menggunakan UBT dan penggerindaan kering, masing-masing pada tiga 
Tabel 1. Analisis Varian pada Temperatur

\begin{tabular}{|c|c|c|c|c|c|}
\hline Faktor & Type & Levels & Values & & \\
\hline $\begin{array}{l}\text { Jenis } \\
\text { Pendinginan }\end{array}$ & Fixed & 2 & 1,2 & & \\
\hline $\begin{array}{l}\text { Kecepatan } \\
\text { Meja }\end{array}$ & Fixed & 3 & $132,191,250$ & & \\
\hline $\begin{array}{l}\text { Kedalaman } \\
\text { Pemakanan }\end{array}$ & Fixed & 3 & $\begin{array}{l}0.01,0.02 \\
\quad 0.03\end{array}$ & & \\
\hline Source & $\mathrm{DF}$ & Seq SS & Adj MS & $\mathrm{F}$ & $\mathrm{P}$ \\
\hline $\begin{array}{l}\text { Jenis } \\
\text { Pendinginan }\end{array}$ & 2 & 210.1 & 210.1 & 0.67 & 0.428 \\
\hline $\begin{array}{l}\text { Kecepatan } \\
\text { meja }\end{array}$ & 2 & 279.6 & 139.8 & 0.45 & 0.649 \\
\hline $\begin{array}{l}\text { Kedalaman } \\
\text { Pemakanan }\end{array}$ & 2 & $7730 . .2$ & 3865.1 & 12.41 & 0.001 \\
\hline Error & 12 & 3738.6 & 311.5 & & \\
\hline Total & 17 & 11958.5 & & & \\
\hline
\end{tabular}

Tabel 2. Hasil Uji Duncan pada Kecepatan Meja

\begin{tabular}{ccc}
\hline Kecepatan Meja & N & Subset 1 \\
\hline 250 & 6 & 374.4667 \\
191 & 6 & 375.6333 \\
132 & 6 & 385.3500 \\
Sig. & & .423 \\
\hline
\end{tabular}

level kecepatan meja dan satu level kedalaman pemakanan. Dari gambar 1 terlihat bahwa kedua cara penggerindaan mempunyai kecenderungan untuk menghasilkan temperatur permukaan benda kerja yang menurun pada ketiga level kedalaman pemakanan.
Tabel 3. Hasil uji Duncan pada Kedalaman Pemakanan

\begin{tabular}{cccc}
\hline $\begin{array}{c}\text { Kedalaman } \\
\text { Pemakanan }\end{array}$ & N & \multicolumn{2}{c}{ Subset } \\
\hline 0.01 & 6 & 356.1333 & $\mathbf{2}$ \\
0.02 & 6 & 371.5833 & \\
0.03 & 6 & & 405.7333 \\
Sig. & & .155 & 1.000 \\
\hline
\end{tabular}

Gambar 2 menunjukkan temperatur permukaan hasil penggerindaan dengan menggunakan UBT dan penggerindaan kering, masing-masing pada tiga level kedalaman pemakanan dan satu level kecepatan meja. Dari gambar 2 terlihat bahwa kedua cara penggerindaan mempunyai kecenderungan menghasilkan temperatur permukaan yang meningkat pada ketiga level kecepatan meja.

Untuk temperatur permukaan, penggerindaan dengan UBT menghasilkan kekasaran permukaan yang lebih rendah dibandingkan dengan penggerindaan kering. UBT berfungsi sebagai pendingin yang efisien, mengurangi friksi antara benda kerja dan gerinda, menghilangkan geram dari daerah penggerindaan, menghilangkan geram dari ruangan diantara grit batu gerinda. Dengan demikian gerinda akan tetap tajam sehingga memungkinkan untuk mengambil material dengan cara shearing, dan sebagian dengan pematahan. Oleh karena itu, temperatur permukaan yang dihasilkan menjadi berkurang jika dibandingkan dengan penggerindaan kering.
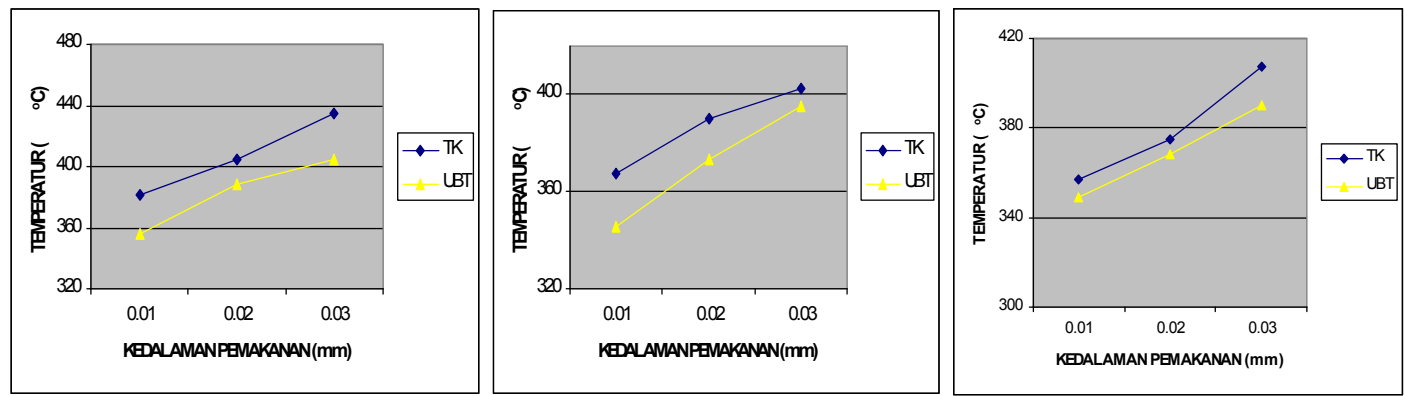

Gambar 1. Grafik temperatur dengan kecepatan meja $132 \mathrm{~mm} / \mathrm{s}, 191 \mathrm{~mm} / \mathrm{s}$, dan $250 \mathrm{~mm} / \mathrm{s}$
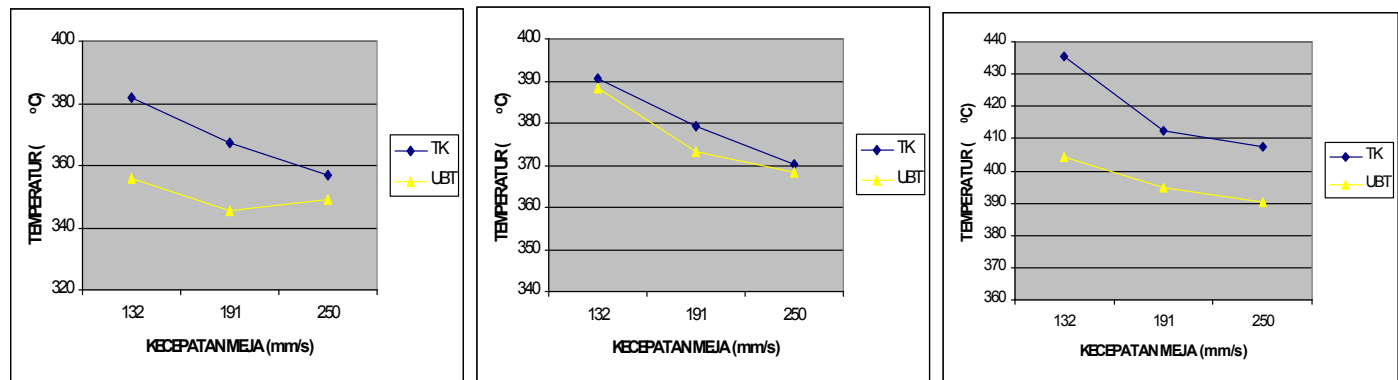

Gambar 2. Grafik temperatur dengan kedalaman pemakanan 0,01 mm,0,02 mm, dan $0,03 \mathrm{~mm}$ 
Tabel 4. Analisis Varian pada kekasaran permukaan

\begin{tabular}{|c|c|c|c|c|c|}
\hline Faktor & Type & Levels & Values & & \\
\hline $\begin{array}{l}\text { Jenis } \\
\text { Pendinginan }\end{array}$ & Fixed & 2 & 1,2 & & \\
\hline $\begin{array}{l}\text { Kecepatan } \\
\text { Meja }\end{array}$ & Fixed & 3 & $132,191,250$ & & \\
\hline $\begin{array}{l}\text { Kedalaman } \\
\text { Pemakanan }\end{array}$ & Fixed & 3 & $\begin{array}{c}0.01,0.02 \\
0.03\end{array}$ & & \\
\hline Source & $\mathrm{DF}$ & Seq SS & Adj MS & $\mathrm{F}$ & $\mathrm{P}$ \\
\hline $\begin{array}{l}\text { Jenis } \\
\text { Pendinginan }\end{array}$ & 2 & 0.0053389 & 0.0053389 & 67.84 & 0.000 \\
\hline $\begin{array}{l}\text { Kecepatan } \\
\text { meja }\end{array}$ & 2 & 0.0040333 & 0.0020167 & 25.62 & 0.000 \\
\hline $\begin{array}{l}\text { Kedalaman } \\
\text { Pemakanan }\end{array}$ & 2 & 0.0065333 & 0.0032667 & 41.51 & 0.000 \\
\hline Error & 12 & 0.0009444 & 0.0000787 & & \\
\hline Total & 17 & 0.0168500 & & & \\
\hline
\end{tabular}

Dengan menggunakan analisis variansi yang hasilnya ditunjukkan pada Tabel 4, dapat diketahui bahwa ketiga faktor, yaitu kondisi penggerindaan, kecepatan meja dan kedalaman pemakanan, secara statistik mempunyai pengaruh yang signifikan pada alpha $=10 \%$.

Hasil uji Duncan yang ditunjukkan pada Tabel 5 menunjukkan bahwa kedua faktor kecepatan meja 132 dan 191 adalah sama, 191 dan 250 adalah sama, tetapi kecepatan meja 132 berbeda dengan 250 .
Tabel 5. Hasil Uji Duncan Pada Kecepatan Meja

\begin{tabular}{cccc}
\hline \multirow{2}{*}{ Kecepatan Meja } & \multirow{2}{*}{ Subset } \\
& & $\mathbf{1}$ & $\mathbf{2}$ \\
\hline 250.00 & 9 & .4733 & \\
191.00 & 9 & .4917 & .4917 \\
132.00 & 9 & & .5100 \\
Sig. & & .219 & .219 \\
\hline
\end{tabular}

Tabel 6. Hasil uji Duncan pada Kedalaman Pemakanan

\begin{tabular}{ccc}
\hline Kedalaman Pemakanan & N & Subset 1 \\
\hline 0.01 & 9 & .4967 \\
0.02 & 9 & .4917 \\
0.03 & 9 & .4867 \\
Sig. & & .514 \\
\hline
\end{tabular}

serta kedalaman pemakanan pada masing-masing level adalah sama.

Gambar 3 menunjukkan kekasaran permukaan hasil penggerindaan dengan menggunakan UBT dan penggerindaan kering, masing-masing pada tiga level kecepatan meja dan satu level kedalaman pemakanan. Dari gambar 3 terlihat bahwa kedua cara penggerindaan mempunyai kecenderungan untuk menghasilkan kekasaran permukaan benda kerja yang menurun pada ketiga level kedalaman pemakanan.
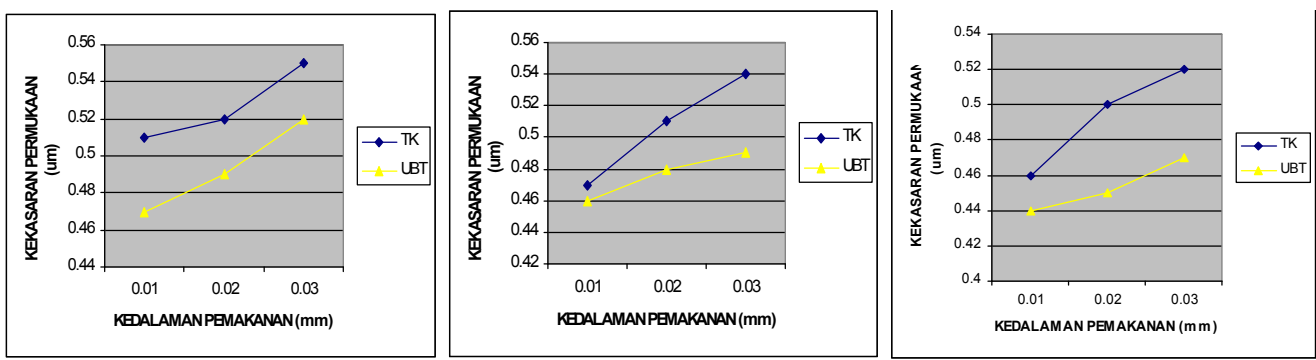

Gambar 3. Grafik kekasaran permukaan dengan kecepatan meja 132 mm/s, 191 mm/s, dan $250 \mathrm{~mm} / \mathrm{s}$
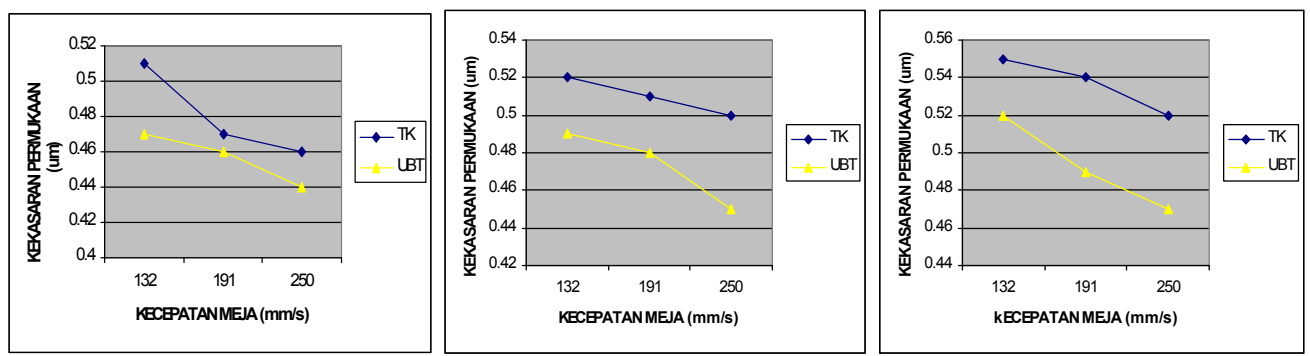

Gambar 4. Grafik kekasaran permukaan dengan kedalaman pemakanan 0,01 mm, 0,02 $\mathrm{mm}$, dan $0,03 \mathrm{~mm}$ 
Gambar 4 menunjukkan kekasaran permukaan hasil penggerindaan dengan menggunakan UBT dan penggerindaan kering, masing-masing pada tiga level kedalaman pemakanan dan satu level kecepatan meja. Dari Gambar 4 terlihat bahwa kedua cara penggerindaan mempunyai kecenderungan untuk menghasilkan kekasaran permukaan yang meningkat pada ketiga level kecepatan meja.

Jenis pendinginan dengan menggunakan udara bertekanan tinggi (UBT) akan menghasilkan kekasaran permukaan yang lebih rendah dibandingkan dengan penggerindaan dengan temperatur kamar (TK). Penambahan kecepatan meja akan membuat kekasaran permukaan yang dihasilkan pada proses penggerindaan akan semakin rendah. Hal ini disebabkan dengan penambahan kecepatan meja akan membuat temperatur penggerindaan semakin menurun. Dengan rendahnya temperatur penggerindaan yang terjadi, maka kekasaran permukaan yang terjadi akan semakin rendah. Dengan semakin besar kecepatan meja, maka semakin cepat gesekan yang terjadi antara permukaan benda kerja dengan batu gerinda. Hal ini akan berakibat terhadap semakin rendahnya kekasaran permukaan yang terjadi pada proses penggerindaan. Selain itu bila kedalaman pemakanan bertambah, permukaan benda kerja akan semakin bertambah kekasarannya. Bertambahnya kekasaran ini disebabkan oleh adanya penambahan luas bidang kontak antara batu gerinda dengan benda kerja. Penambahan luasan benda kerja yang bergesekan dengan batu gerinda akan menurunkan kecepatan meja, sehingga kekasaran permukaan benda kerja pada proses penggerindaan akan semakin tinggi.

Nguyen (2003) menjelaskan penggunaan kedalaman pemakanan yang besar akan membuat kekasaran permukaan akan semakin tinggi (kasar). Pemakaian kedalaman pemakanan yang kecil, akan membuat mata potong yang terdapat di permukaan batu gerinda akan sedikit yang bergesekan dengan benda kerja. Gesekan yang kecil itu akan menyebabkan permukaan hasil penggerindaan mempunyai celah yang kecil, sehingga hasil penggerindaan akan berpengaruh pada harga kekasaran permukaan yang semakin halus. Akan tetapi sebaliknya dengan pemakaian kedalaman pemakanan yang besar, maka mata potong yang terdapat di permukaan batu gerinda akan lebih banyak yang bergesekan dengan benda kerja. Sehingga akan menyebabkan permukaan hasil penggerindaan mempunyai celah yang besar, sehingga hasil penggerindaan berpengaruh terhadap harga kekasaran permukaan yang semakin tinggi.

Hasil penelitian Janone (2002) menjelaskan penggunaan cairan pendingin yang sesuai akan berfungsi sebagai pelumas yang sangat efektif. Cairan pendingin dengan udara bertekanan tinggi (UBT) akan berfungsi sebagai pendingin yang efisien, mengurangi friksi antara benda kerja dan batu gerinda, menghilangkan geram dari daerah penggerindaan, dan menghilangkan geram dari ruangan diantara grit-grit batu gerinda. Dhar (2006) menjelaskan penggunaan cairan pendingin bertekanan tinggi akan mengurangi pengikisan pada batu gerinda. Hal ini akan membuat batu gerinda akan tetap tajam sehingga memungkinkan untuk mengambil material dengan cara shearing, dan sebagian dengan pematahan. Pemakaian cairan pendingin bertekanan tinggi dapat menghasilkan kekasaran permukaan benda kerja yang rendah. Kekasaran permukaan yang rendah ini diakibatkan oleh masuknya sebagian cairan pendingin ke dalam celah-celah yang ada pada permukaan benda kerja.

\section{SIMPULAN}

Hasil penelitian yang telah dilakukan tentang proses gerinda permukaan menggunakan kedalaman pemakanan, kecepatan meja, dan cairan pendingin bertekanan tinggi adalah semakin tinggi temperatur penggerindaan dipengaruhi oleh semakin besar kedalaman pemakanan, tanpa menggunakan cairan pendingin, dan kecepatan meja tidak berpengaruh terhadap temperatur penggerindaan. Sedangkan semakin rendah kekasaran permukaan dipengaruhi oleh semakin tinggi kecepatan meja, semakin kecil kedalaman pemakanan dan penggunaan cairan pendingin.

\section{DAFTAR PUSTAKA}

Babic, D.M., A.A. Torrance, and D.B. Murray, 2000. Soap Mist Jet Cooling of Grinding Processes, Journal of Machine Tool Manufacture Design and Research 2000.

Dhar, N.R., A.T. Siddiqui, and M.H. Rashid, 2006. Effect of High-Pressure Coolant Jet on Grinding Temperature, Chip and Surface Roughness in Grinding AISI-1040 Steel, ARPN Journal of Engineering and Applied Sciences, Vol. 1: 22-28.

Guo, C, and S. Malkin, 1996. Inverse Heat Transfer Analysis of Grinding, Part 2: Aplications, Journal of Engineering for Industry, Vol. 118: 143-149.

Jannone, E, da Silva., Eduardo, C.B., Joao, F.G, de Oliveira, and Paulo, R, de Aguiar, 2002. The Inlet Engine Valve Grinding Using Different Types of Cutting Fluids and Grinding Wheels, Materials Research, Vol. 5, No. 2, 187-194.

Nguyen, T, and L.C. Zhang, 2003. An Assessment of the Applicability of Cold Air and Oil Mist in Surface Grinding, Journal of Materials Processing Technology 140: 224-230. 